\title{
Degrees Held by Head Librarians Of Colleges and Universities
}

By JOHN CALDWELL

$\mathrm{I}^{\mathrm{N}}$ "Standards for College Libraries" adopted by ACRL in 1959, it is recommended that a college library ". . . be operated by a broadly educated and highly qualified staff of professional librarians, under the direction of a chief librarian. The professional librarian is defined as one holding a professional degree." 1 This paper is an investigation of the educational backgrounds of the head librarians in American colleges and universities to find in what degree they meet this minimum standard.

A list of all college and university librarians who direct libraries with book collections greater than fifty thousand volumes was compiled from the American Library Directory (21st ed., 1960). This produced a list of 545 names. These names were checked through Who's Who in Library Service (3d ed., 1955) to collect data on their formal education. If this produced no information, the remaining names were checked in Who's Who in America (Vol. 31, 1960); Directory of American Scholars (3d ed., 1957); and Who's Who of American Women (Vol. 1, 1958). For some names, entries in the catalogs of the institutions where they are librarians provided enough educational information. Finally seventyfour names had to be eliminated because sufficient information could not be found about them. The final list, made up of the names of 471 librarians, was divided into five sections according to the size of the book collection: over $1,000,000$ volumes; 500,000 to $1,000,000 ; 250,000$ to

1 "'Standards for College Libraries," CRL, XX (1959),
Mr. Caldwell is Librarian, California Lutheran College, Thousand Oaks, Calif.

500,$000 ; 100,000$ to 250,000 ; and 50,000 to 100,000 .

The bachelor's degree is generally considered to be the minimum formal indication of the "broadly educated"; this degree is held by 468 of the librarians investigated. The majority of these librarians, 380, hold the B.A. degree, the others hold the basic degree in a variety of forms: B.S. 52, undergraduate B.L.S. 17, Ph.D. 11, Ed.D. 7, Litt.D. 1. Thirteen of these librarians have no other formal education and ninety-one others have in addition only a B.L.S. ${ }^{2}$ or a certificate from a library school. Master's degrees, in something other than library studies, have been earned by 211 of the librarians: M.A. 194, M.S. 10, Ed.M. 4, Litt.M. 2, M.B.A. 1. For 150 the master's degree is the terminal degree, although 124 of those with this degree have also some library degree. The M.L.S. ${ }^{3}$ is the terminal degree for 127 other librarians. Eightyeight of the librarians have a doctorate of some kind: 55 have the $\mathrm{Ph} . \mathrm{D}$. in some subject area, 2 the Ed.D., and 31 a Ph.D. in library studies. In all, 410 librarians hold a library degree of some kind; 61 (13 per cent) do not have library degrees, though 11 attended library school.

There are 22 universities with collections of more than one million volumes.

2 B.L.S. and M.L.S. are used throughout for all bachelor's and master's degrees in library studies.

3 Ibid. 


\begin{tabular}{|c|c|c|c|c|c|c|}
\hline & 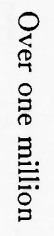 & 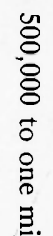 & $\begin{array}{l}\text { N } \\
\text { O } \\
8 \\
8 \\
0 \\
0 \\
\text { un } \\
8 \\
0 \\
8\end{array}$ & $\begin{array}{l}\overrightarrow{8} \\
\dot{8} \\
8 \\
0 \\
\text { N } \\
\text { ஸे } \\
\dot{8}\end{array}$ & $\begin{array}{l}\text { n } \\
8 \\
8 \\
8 \\
0 \\
: \\
8 \\
8\end{array}$ & 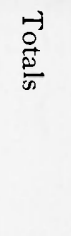 \\
\hline Number of librarians surveyed & 21 & 37 & 63 & 135 & 215 & 471 \\
\hline $\begin{array}{l}\text { Bachelor's degree } \\
\text { Bachelor's only degree } \\
\text { Bachelor's plus library degree or degrees }\end{array}$ & $\begin{array}{r}21 \\
1 \\
0\end{array}$ & $\begin{array}{r}37 \\
1 \\
4\end{array}$ & $\begin{array}{r}63 \\
2 \\
10\end{array}$ & $\begin{array}{r}133 \\
3 \\
21\end{array}$ & $\begin{array}{r}214 \\
6 \\
56\end{array}$ & $\begin{array}{r}468 \\
13 \\
91\end{array}$ \\
\hline $\begin{array}{l}\text { Subject master's degree } \\
\text { Subject master's terminal } \\
\text { Subject master's plus library degree or degrees } \\
\text { M.L.S. terminal degree }\end{array}$ & $\begin{array}{l}9 \\
0 \\
2 \\
3\end{array}$ & $\begin{array}{r}16 \\
3 \\
4 \\
9\end{array}$ & $\begin{array}{r}32 \\
6 \\
18 \\
14\end{array}$ & $\begin{array}{l}72 \\
10 \\
38 \\
35\end{array}$ & $\begin{array}{r}82 \\
7 \\
62 \\
66\end{array}$ & $\begin{array}{r}211 \\
26 \\
124 \\
127\end{array}$ \\
\hline $\begin{array}{l}\text { Doctor's degree in subject } \\
\text { Doctor's degree in library studies } \\
\text { Doctor's degree plus library degree or degrees }\end{array}$ & $\begin{array}{l}7 \\
8 \\
3\end{array}$ & $\begin{array}{l}8 \\
8 \\
4\end{array}$ & $\begin{array}{l}7 \\
6 \\
3\end{array}$ & $\begin{array}{r}21 \\
7 \\
13\end{array}$ & $\begin{array}{l}14^{*} \\
2 \\
10\end{array}$ & $\begin{array}{l}57^{*} \\
31 \\
33\end{array}$ \\
\hline No library degree & 5 & 8 & 11 & 19 & 18 & 61 \\
\hline $\begin{array}{l}\text { Total holding library degrees } \\
\text { Certificate, no library degree } \\
\text { B.L.S. only library degree } \\
\text { M.L.S. only library degree } \\
\text { Ph.D. only library degree } \\
\text { Certificate or B.L.S. plus M.L.S. } \\
\text { Certificate or B.L.S. plus M.L.S. and Ph.D. } \\
\text { Certificate or B.L.S. plus Ph.D. }\end{array}$ & $\begin{array}{r}16 \\
1 \\
4 \\
1 \\
1 \\
2 \\
2 \\
5\end{array}$ & $\begin{array}{r}29 \\
1 \\
11 \\
2 \\
0 \\
7 \\
2 \\
6\end{array}$ & $\begin{array}{r}52 \\
2 \\
26 \\
4 \\
0 \\
14 \\
2 \\
4\end{array}$ & $\begin{array}{r}116 \\
8 \\
59 \\
13 \\
0 \\
29 \\
3 \\
4\end{array}$ & $\begin{array}{r}197 \\
8 \\
100 \\
36 \\
0 \\
51 \\
0 \\
2\end{array}$ & $\begin{array}{r}410 \\
20 \\
200 \\
56 \\
1 \\
103 \\
9 \\
21\end{array}$ \\
\hline
\end{tabular}

* Includes 2 Ed.D.

One of these was without a librarian when the list was compiled; educational information was obtained on the librarians of the others. All of these have a bachelor's degree; 9 of them have a subject master's degree; and 15 of them have a doctorate: 7 in a subject field and 8 in library studies. One of these university librarians holds no degree beyond the B.A.; for 2 others the M.A. is the terminal degree, although these also have a B.L.S.; 3 more hold the M.L.S. but have no subject master's degree. In this group of 21 librarians, 5 (23.8 per cent) have no library degree. Of the 7 who have doctorates in a subject field, 3 also have a library degree.

Of the 37 librarians of libraries of between 500,000 and 1,000,000 volumes. all have a bachelor's degree. For one li- brarian this is the only degree, 3 have only the B.L.S. in addition, and 1 other both the B.L.S. and the L.L.B. Sixteen of these librarians have a master's degree in a subject field and for 7 of them it is the terminal degree, although 2 of the 7 have the B.L.S., one both the B.L.S. and the L.L.B., and 1 a library school certificate; 9 other librarians hold the M.L.S. as their highest degree. Sixteen of the librarians in this group have doctorates, half in subject fields and half in library studies. Eight (21.6 per cent) of the 37 librarians do not have library degrees, although two of these have attended library schools without taking degrees. Of the 8 holding subject Ph.D.'s, 4 also have library degrees.

(Continued on page 260) 
Degrees Held ...

(Continued from page 228)

There are 65 libraries with collections of between 250,000 and 500,000 volumes: for the librarians of 2 of these, no educational information was found; of the remaining 63, all have the bachelor's degree, 2 of these librarians have no other degrees, 9 others have a B.L.S. in addition to the undergraduate degree, and 1 has a library school certificate. Thirtytwo librarians in this group have an M.A. and for 24 of them it is the highest degree held, although 14 have in addition the B.L.S., I has the M.L.S., I a certificate, and 2 have both the B.L.S. and M.L.S. For 14 additional librarians, the M.L.S. is the only master's degree. There are 13 librarians in this group with doctorates -7 in subject fields and 6 in library studies. Eleven (17.4 per cent) of these 63 librarians do not have a library degree, the other 52 have certificates, B.L.S., M.L.S., and library studies doctorates in various combinations, although 2 have only the certificate and 26 only the B.L.S. Three librarians do not have library degrees although they have attended library school. Of those holding a doctorate in a subject field, 3 have library degrees.

Of the next group of libraries, those having between 100,000 and 250,000 volumes, educational information was found on 135 librarians of a possible 154. All but 2 of these librarians have a bachelor's degree; I of them has only a certificate from a library school, the other received a diploma from a seminary and later acquired both a library degree and an M.A. For 24 librarians, the bachelor's degree is terminal, although 21 of them have in addition the B.L.S. and I of these has also the L.L.B. Seventy-two librarians in this group have a subject master's degree; for 48 of them, it is the highest degree, although 38 also have a library degree or degrees. For 35 librarians, the M.L.S. is the only master's degree. There are 28 librarians in this group who hold the doctor's degree-21 in a subject area and 7 in library studies. Library degrees are held by a total of 116 librarians in this group; of the 19 (14 per cent) who do not have library degrees, 3 have attended a library school for some period. Thirteen of those who have subject doctorates also have a library degree.

The final group of librarians to be surveyed supervise libraries with fewer than 100,000 volumes but with more than 50,000. The American Library Directory lists 268 libraries of this size, but educational information could be found for the librarians of only 215 of them. All but 1 of these librarians has the bachelor's degree; this librarian attended college, but did not take a degree. For 64 the bachelor's degree is terminal, although all but 6 have had further professional education, and 56 of them have graduated from library school, and 2 from theological seminaries. Subject master's degrees are held by 82 of these librarians; this is the terminal degree for 69 of them, but 63 of these have library degrees. For 66 others the M.L.S. is the only master's degree held. Twelve librarians in this group have a subject Ph.D., 2 have doctorates in library studies, and 2 the Ed.D. A library degree is held by 197 of the 215 librarians; of the 18 (8.4 per cent) who do not have library degrees, 6 have attended library schools. Eight of the subject doctorates and both of the doctorates of education also hold a library degree.

This brief survey of the educational backgrounds of our head college and university librarians has shown that as a group they meet the standards set by the profession and move beyond them. They are broadly educated: only 13 of 468 who hold the bachelor's degree have terminated their formal education at that point, 338 have at least one master's degree, and 88 have doctorates. Although 61 do not have degrees in library studies, 11 of them have attended library school, leaving only 50 who do not have formal library education of some kind. 